\title{
The Effect of Sugarcane Bagasse Ash on the Properties of Portland Limestone Cement
}

\author{
Olubajo Olumide Olu*, Nuuman Aminu, Likita Nazif Sabo \\ Department of Chemical Engineering, Faculty of Engineering, Abubakar Tafawa Balewa University, Bauchi, Nigeria \\ Email address: \\ ooolubajo@atbu.edu.ng (O. O. Olu), aminunuuman@gmail.com (N. Aminu), nazifsabolikita1993@gmail.com (L. N. Sabo) \\ ${ }^{*}$ Corresponding author
}

\section{To cite this article:}

Olubajo Olumide Olu, Nuuman Aminu, Likita Nazif Sabo. The Effect of Sugarcane Bagasse Ash on the Properties of Portland Limestone Cement. American Journal of Construction and Building Materials. Vol. 4, No. 2, 2020, pp. 77-87. doi: 10.11648/j.ajcbm.20200402.15

Received: November 7, 2020; Accepted: November 21, 2020; Published: December 4, 2020

\begin{abstract}
This paper tries to investigate sugarcane bagasse ash (SCBA) as a cement replacement material and its effect on the water consistency, setting times, soundness, specific gravity, water absorption and mortar compressive strength of SCBA-Portland limestone cement (PLC) blend at cement replacement from $0-15 \mathrm{wt} . \%$ at interval of $2.5 \mathrm{wt} . \%$. Calcination of sugarcane bagasse was conducted and the optimum condition was obtained ash at $650^{\circ} \mathrm{C}$ at 90 mins with a higher $\mathrm{Si}+\mathrm{Al}+\mathrm{Fe}$ content from nine compositional analysis of ashes obtained via X-ray fluorescence spectrometer and then employed as cement replacement material for this research work. The consistency and setting times of the blended cement samples were carried on paste using Vicat apparatus while the soundness, specific gravity and compressive strength using Le Chatelier apparatus, density bottle and strength testing machine respectively according to ASTM standards respectively. Results showed an increase in the water consistency and setting times of SCBA cement pastes as SCBA content was increased from $2.5-15 \mathrm{wt} . \%$ which was attributed to unburnt carbon present in the ash due to its high LOI. The elongated setting times could also due to clinker diminution by cement replacement with SCBA and high-water demand. The SCBA cement blends produced accelerated setting time results compared to PLC owing to lime present in SCBA which enhances early hydration. The specific gravity diminished while the volume expansion of the SCBA cement pastes experienced an increase as SCBA was increased due to lower density of SCBA compared to PLC and increased lime content due to increased SCBA content respectively. An increase in the mortar compressive strengths of SCBA cement blends was experienced as the curing days progressed from 3 to 60 days. PLC blended with SCBA produced an enhanced early strength due to the presence of lime which tends to accelerate the rate of formation of hydration assembly. Whereas, at a high cement replacement of $12.5 \mathrm{wt} . \%$ SCBA produced exceptional mortar compressive strength especially at 60 days despite clinker diminution indicating pozzolanic activity due to SCBA inclusion. The optimal cement replacement with SCBA was observed at $5 \mathrm{wt} . \%$ in comparison with control especially at 28 days and did not adversely affect its strength owing to pozzolanic activity.
\end{abstract}

Keywords: Sugar Bagasse Ash, Consistency, Setting Times, Soundness, Compressive Strength

\section{Introduction}

Concrete is one of the most essential construction materials for buildings, bridges and roads and is globally dependent on its cost effectiveness, easily fabricated into various structural shapes and its durability [1, 2]. Its importance in the construction and building sectors crests as a catalyst in a nations' infrastructural development; to meet up with this rapid infrastructural development. A huge quantity of concrete is required of which cement constitutes approximately $10-15 \%$ of its weight [3]. The drastic depletion of limestone reserves adds to the cost of cement production owing to the fact that limestone is the chief material [4]. In order to reduce cost, partial cement replacement has been considered which has opened new research frontiers. The use of waste materials that contain minerals or compounds that could enhance the cement properties and in turn ultimately reduce the cost of cement production. Various materials such as rice husk ash, saw dust ash, orange peel ash, bottom ash, fly ash, eggshell powder 
and silica fumes have already been identified and are being used as partial cement replacement [5-8].

One of the most effective ways of reducing this waste management issue, cost and conserve energy is the incorporation of supplementary cementitious materials (SCM) which can serve as a partial cement replacement for both concrete and mortar [9]. The use of SCMs could be found in various forms either naturally or synthetically to improve the compressive strength, pore structure, and permeability (reduction in the total porosity) of mortars or concretes with increasing hydration time [10]. Sugarcane contains about $25-30 \%$ bagasse (with 50\% moisture content) and residual ash of $0.62 \%$ whereas, sugarcane bagasse consists of approximately $50 \%$ cellulose, $25 \%$ hemicelluloses of lignin $[11,23]$. A limited amount of SCBA has been used as soil amendment while the rest is useless causing serious environmental impacts. Although, sugarcane bagasse is a valueless agricultural waste of sugar industry, its ash possesses pozzolanic properties which could be beneficial as a cement replacement material due to its high $\mathrm{SiO}_{2}$ content. The use of renewable sources through wastes from industries and environment is the way forward because they are naturally replenished and would not only eliminate the problem of natural resource depletion but also tackle the problem of environmental pollution i.e. non-biodegradability of dumped wastes. Sugarcane bagasse as a waste product can be found littered around the environment and most sugar industries can be considered as a renewable source. Due to the high demand for energy, bagasse owing to its high calorific value has the potentials of be employed in the generation of electricity, while the resultant ash could provide enhanced physico-mechanical properties, if employed as a cement replacement material.

A pozzolana is a siliceous or siliceous and aluminous material, occurring either naturally or artificially, and which contains silica, iron and aluminium ions which in itself possess little or no cementitious value, but one which in finely divided form and in the presence of moisture, will chemically react with calcium hydroxide at ordinary temperatures to form compounds possessing cementitious properties $[12,13]$. The application of pozzolanic materials has been extended to the development of high-performance concretes used for constructions of high specifications [14]. The use of pozzolans in the production of mortar/ concrete brings several positives ranging from curbing environmental issues associated with their disposal to reduction in the emission of greenhouse gases $\left(\mathrm{CH}_{4}\right.$ and $\left.\mathrm{CO}_{2}\right)$ which results in global warming being reduced by replacement of cement. The inclusion of SCMs can affect the properties of cement mortar/concrete both in fresh (mix proportions, water requirement for specified consistency, setting characteristics, workability including cohesiveness and bleeding, and heat of hydration) and hardened state (the rate of strength development and ultimate strength, permeability, durability against frost attack, sulphate attack, alkali silica reaction, carbonation, and resistance to thermal cracking). The pozzolanic activity of SCBA can be linked to the silicon content of the ash and its content may vary depending on the burning and other properties of raw material [15]. The silicon present in the ash undergoes pozzolanic reaction with hydration products of cement in order to reduce the free lime.

Sachin et al. [16] conducted an experiment to investigate the effect of replacing SCBA on the fresh properties of cement up to $30 \%$ at interval of $5 \%$ and observed that SCBA resulted in a significant increase in the consistency (water demand) by $30-45 \%$ while a retardation in both setting times were observed from 180-297 and 390-450 minutes respectively. Modani and Vyawahare [17] observed that at $10 \%$ fine aggregate replacement with SCBA, the compressive strength produced a higher strength compared to control, whereas any further increase in SCBA content resulted in a decrease in its strength. Similarly, the rate of strength gain of the mixes blended with SCBA were higher at the later days due to SCBA's pozzolanic properties and concluded that aggregates replacement of $10-20 \%$ can be effectively replaced with untreated SCBA without considerable loss of workability and strength. Hussein et al. [18] replaced cement with SCBA from $5-50 \%$ and observed that $30 \%$ SCBA showed significant improvement at 90 and 180 days indicating SCBA excellent pozzolanicity especially up to $20 \%$ which was attributed to SCBA high silica content and the ultra-fine particle size (most below $45 \mu \mathrm{m}$ ) which enhances pozzolanic activity and thus, significantly improves the early strength. Chusilp et al. [19], Ganesan et al. [20], Srinivasan [21] and Suvimol and Daungruedee [22] agreed with findings by Hussein et al. [18]. Prakash [3] investigated the effect of replacing cement with SCBA for 5,10 and $15 \%$ on the concrete strength at 7,14 and 28 days with $10 \%$ SCBA replacement exhibiting the best strength gain by $1.74 \%, 5.34 \%$ and $1.82 \%$ against control strength for 7, 14 and 28 days respectively due to pozzolanic properties of bagasse ash. Bhargavi and Murali [23] investigated the effect of replacing cement with SCBA between $0-25 \%$ which was prepared by calcining sugar cane bagasse at $1200^{\circ} \mathrm{C}$ for 5 hours on the strengths and observed that the optimal strength was obtained at 5\% cement replacement and cement replacement beyond $15 \%$ produced lower 7 and 28 days flexural, compressive and tensile strengths in comparison with control. Mashair and Kamal [24] studied the effect of replacing local materials such as pozzolans, local sand and SCBA on the mortar compressive strength for 2, 7 and 28 days and observed that the inclusion of 5 and 10\% local materials led to enhanced mortar compressive strength but beyond $10 \%$ cement replacement led to a reduction in its strengths. Bangar et al. [25] studied the effect of replacing cement with SCBA between $2-10 \%$ at interval of $2 \%$ on the concrete compressive strength. It was observed that beyond $8 \%$ cement replacement, the SCBA cement blends produced lower compressive strengths which could be due to clinker diminution. The enhanced strengths at lower cement replacements were linked to the relative fineness, SCBA pozzolanic activity as well as the existing crystalline silica $\left(\mathrm{SiO}_{2}\right)$. Geerthana et al. [26] studied the possibility of using SCBA as a partial cement replacement material and observed that as the SCBA content increased from $10-20 \%$, the specific gravity decreased while the fineness, consistency and setting 
times experienced increments. Results also showed that $20 \%$ SCBA concrete produced significantly higher compressive strength compared with control. Sivakumar et al. [27] compared the performance of $10 \%$ SCBA cement blend and control based on the morphology and chemical analysis via SEM-EDS, FTIR and XRF. The SEM-EDS results indicated that cement phases such as $\mathrm{C}_{2} \mathrm{~S}, \mathrm{C}_{3} \mathrm{~S}, \mathrm{C}_{4} \mathrm{AF}$ and $\mathrm{C}_{3} \mathrm{~A}$ were presence in cement while SCBA depicted prismatic particles signifying Si only. The spherical one contained $\mathrm{Si}$ as well as $\mathrm{Ca}, \mathrm{Al}, \mathrm{Fe}, \mathrm{Na}, \mathrm{K}$ with $70 \% \mathrm{Si}$ in the ash. The authors concluded that the cement gained more strength than control due to pozzolanic reaction with SCBA stemming from reactive silica SCBA obtained from calcining at $650^{\circ} \mathrm{C}$ for 2 hrs at heating rate of $10^{\circ} \mathrm{C} / \mathrm{min}$ and then ground and sieved. The FTIR results indicated a sharp band was obtained at 3641 $\mathrm{cm}^{-1}$ due to $\mathrm{OH}$ stretching vibrations $v 3$ for the hydration product $\mathrm{Ca}(\mathrm{OH})_{2}$. These techniques were able to justify that more CSH were formed with SCBA blend and thus enhancing the hydration and thus the strength. Reddy et al. [28] investigated the effect of replacing cement with $0-20 \%$ SCBA obtained by burning the bagasse btw $700-6000{ }^{\circ} \mathrm{C}$ for 72 hours and then sieved with BS standard sieve of $75 \mu \mathrm{m}$ on concrete properties and observed that at $10 \%$ SCBA produced an enhanced compressive strength of $30.57 \mathrm{~N} / \mathrm{mm}^{2}$ as against $23.43 \mathrm{~N} / \mathrm{mm}^{2}$. Cement replacement with $20 \%$ SCBA indicated a slight compared to control for both 7- and 28-days compressive strength. Mangi et al. [29] studied partial replacement for two grades M15 and M20 with SCBA for 0, 5 and $10 \%$ and observed that partial replacement led to an increase in compressive strength of both grades with the optimal at 5\% SCBA. Romildo et al. [30] investigated cement substitution of $5-30 \%$ at interval of $5 \%$ with $15 \%$ substitution was obtained as the optimum substitution and observed that burning fire process employed influenced the compressive strength of the SCBA cement blend. This research paper tries to determine the process condition of SCBA with the highest pozzolanic reactivity and then investigate its effects on the physico-mechanical properties of cement.

\section{Materials and Method}

\subsection{Materials}

Materials employed in the production of SCBA-cement blends in this study include PLC CEM II 42.5R and SCBA respectively. PLC was obtained from Dangote cement company Plc., while SCBA was obtained from the calcination of sugarcane bagasse collected from Savannah sugar industry. The sugarcane bagasse was sorted to ensure no debris are present and sun dried in order to reduce its moisture content, after which calcination of the sugarcane bagasse at various temperatures and times to establish the optimal condition i.e. temperature and time to obtain SCBA which was the most reactivity. Size reduction of the obtained
SCBA was achieved by using a mortar and pestle followed by sieving with 90-micron sieve. Then the chemical composition of the ash was determined by using X-ray fluorescence spectrometer.

\subsection{Procedure}

The water required for standard consistency and both initial and final setting times of PLC and SCBA cement blends were determined according to ASTM C 187 [34] and ASTM C 191 [35] using the Vicat apparatus as shown in Figures 2 (a) while the volume expansion (soundness) was determined with Le Chatelier apparatus according to EN 196-3 [36]. The specific gravities (densities) of the cement blends were determined according to ASTM C 188 [48]. The mixing of blended cement pastes was carried out with the standard water of consistency as given in Table 4. The specimen compressive strengths were obtained using the Toni Technik compression and bending machine as shown in Figure 2 (b) according to ASTM 109 [47] by mixing water, cement and standard sand at a ratio of 1:3:5 in a mixing machine at $20^{\circ} \mathrm{C}$ with relative humidity not less than $50 \%$. After proper mixing of the mortar, the mix was transferred into the $50 \mathrm{~mm}$ cube moulds and compacted using a standard jolting apparatus and kept in a cabinet for 24 hours. The moulds were then demoulded and placed in curing tank containing water until the strength testing for the curing days of 3, 7, 28 and 60 days. The absorption test was determined by computing the weight difference before and after immersing the mortar in water for curing days 3, 7, 28 and 60 days. The experimental matrix for the determination of the physico-mechanical properties of PLC and SCBA cement blends are tabulated in Table 2.

\section{Results and Discussion}

\subsection{Chemical Composition of the Starting Materials}

The chemical composition of calcined sugarcane bagasse was determined using $\mathrm{X}$-ray fluorescence spectrometer at $600^{\circ} \mathrm{C}, 650^{\circ} \mathrm{C}$ and $700^{\circ} \mathrm{C}$ for 60,90 and 120 minutes are tabulated in Table 3 respectively. The SCBA contains mainly oxides such as Silica, Alumina, Iron, Lime and Potassium oxide. Table 1 indicates the chemical composition of PLC and SCBA at $650^{\circ} \mathrm{C}$ for 90 minutes. Chemical analysis revealed that Sugarcane bagasse calcined at $650^{\circ} \mathrm{C}$ for 90 minutes comprised of more than 70 wt. $\%$ of $\mathrm{SiO}_{2}+\mathrm{Al}_{2} \mathrm{O}_{3}+\mathrm{Fe}_{2} \mathrm{O}_{3}$ (71.79 wt. \%) while $\mathrm{CaO}$ content was 10.59 wt.\% which met class $\mathrm{C}$ with $\mathrm{CaO}$ content $>10 \%$, hence the ash satisfies as a pozzolan according to ASTM C 618 [37]. SCBA had a loss on ignition of $9.27 \mathrm{wt} . \%$ which indicates a high degree of unburnt carbon of ash [38] which is also responsible for increase in the water requirement due to the high porosity of SCBA particle resulting in mixture segregation [39-41]. 
Table 1. Chemical composition of PLC and SCBA.

\begin{tabular}{|c|c|c|c|c|c|c|c|c|}
\hline Oxide & $\begin{array}{l}\text { PLC } \\
\text { wt.\% }\end{array}$ & SCBA wt.\% & $\begin{array}{l}\text { Sivakumar } \\
\text { et al. }[27]\end{array}$ & $\begin{array}{l}\text { Hussein } \\
\text { et al. }[18]\end{array}$ & Reddy et al. [28] & $\begin{array}{l}\text { Anvesh \& } \\
\text { Chamanthi [31] }\end{array}$ & $\begin{array}{l}\text { Yasir } \text { et } \\
\text { al. [32] }\end{array}$ & $\begin{array}{l}\text { Rauf et } \\
\text { al [33] }\end{array}$ \\
\hline Condition & & $650^{\circ} \mathrm{C} 1.5 \mathrm{hr}$ & & & $700-6000^{\circ} \mathrm{C} 7 \mathrm{hr} 75 \mu \mathrm{m}$ & & $5 \% 45 \mu \mathrm{m}$ & $600^{\circ} \mathrm{C}$ \\
\hline $\mathrm{SiO}_{2}$ & 12.39 & 60.33 & 69.31 & 77.25 & 78.34 & 62.47 & 70.34 & 58.24 \\
\hline $\mathrm{Al}_{2} \mathrm{O}_{3}$ & 4.20 & 7.46 & 6.73 & 6.37 & 8.55 & 4.34 & 3.12 & 6.92 \\
\hline $\mathrm{Fe}_{2} \mathrm{O}_{3}$ & 1.95 & 3.91 & 4.35 & 4.21 & 3.61 & 6.99 & 6.29 & 14.34 \\
\hline $\mathrm{CaO}$ & 43.14 & 10.59 & 9.4 & 4.05 & 2.15 & 11.78 & 11.76 & 0.49 \\
\hline $\mathrm{MgO}$ & 0.74 & 0.87 & - & 2.61 & - & - & 1.27 & 3 \\
\hline $\mathrm{SO}_{3}$ & 1.03 & 0.75 & 0.46 & 0.11 & - & - & 0.33 & 0.22 \\
\hline $\mathrm{K}_{2} \mathrm{O}$ & 0.63 & 4.39 & 2.65 & 2.34 & 3.46 & 3.51 & - & - \\
\hline $\mathrm{Na}_{2} \mathrm{O}$ & 0.09 & 1.14 & 0.71 & 1.38 & 0.12 & - & - & - \\
\hline $\mathrm{P}_{2} \mathrm{O}_{5}$ & 0.18 & 0.80 & - & 0.59 & 1.07 & - & - & - \\
\hline $\mathrm{Mn}_{2} \mathrm{O}_{3}$ & 0.10 & 0.13 & - & 0.27 & 0.13 & - & - & - \\
\hline $\mathrm{TiO}_{2}$ & 0.19 & 0.36 & - & 0.58 & 0.5 & - & - & - \\
\hline LOI & 34.67 & 9.27 & 2.33 & - & - & - & 6.76 & - \\
\hline LSF & 105.43 & 5.76 & & & & & & \\
\hline Calcium Carbonate & 79.00 & 18.92 & & & & & & \\
\hline Sum of Conc. & 64.65 & 100.00 & & & & & & \\
\hline $\mathrm{C}_{3} \mathrm{~S}$ & 77.70 & -724.65 & & & & & & \\
\hline Specific gravity & 2.90 & 1.80 & & & & & & \\
\hline Sum of Conc. & 64.65 & 100.00 & & & & & & \\
\hline
\end{tabular}

Table 2. Experimental Matrix for control \& cement blended with SCBA.

\begin{tabular}{llll}
\hline S/No & Cement Blends & PLC $(\mathbf{g})$ & SCBA $(\mathbf{g})$ \\
\hline 1 & PLC & 100.0 & 0.0 \\
2 & 2.5 SCBA & 97.5 & 2.5 \\
3 & 5 SCBA & 95.0 & 5.0 \\
4 & 7.5 SCBA & 92.5 & 7.5 \\
5 & 10 SCBA & 90.0 & 10.0 \\
6 & 12.5SCBA & 87.5 & 12.5 \\
7 & 15SCBA & 85.0 & 15.0 \\
\hline
\end{tabular}

Table 3. Chemical Composition of SCBA at various temperatures and times.

\begin{tabular}{llllllllll}
\hline Component & $\mathbf{6 0 0}^{\circ} \mathbf{C}$ & $\mathbf{6 0 0}^{\circ} \mathbf{C}$ & $\mathbf{6 0 0}^{\circ} \mathbf{C}$ & $\mathbf{6 5 0}^{\circ} \mathbf{C}$ & $\mathbf{6 5 0}^{\circ} \mathbf{C}$ & $\mathbf{6 5 0}^{\circ} \mathbf{C}$ & $\mathbf{7 0 0}^{\circ} \mathbf{C}$ & $\mathbf{7 0 0}^{\circ} \mathbf{C}$ & $\mathbf{7 0 0}^{\circ} \mathbf{C}$ \\
\hline $\mathrm{SCBA}$ & 60 mins & 90 mins & 120 mins & 60 mins & 90 mins & 120 mins & 60 mins & 90 mins & 120 mins \\
$\mathrm{SiO}_{2}$ & 56.44 & 55.60 & 55.03 & 55.91 & 60.33 & 58.46 & 58.54 & 58.36 & 59.43 \\
$\mathrm{Al}_{2} \mathrm{O}_{3}$ & 7.58 & 8.26 & 8.01 & 7.71 & 7.46 & 7.64 & 8.16 & 8.08 & 7.66 \\
$\mathrm{Fe}_{2} \mathrm{O}_{3}$ & 3.17 & 3.06 & 3.09 & 3.12 & 3.91 & 2.92 & 3.07 & 3.22 & 3.61 \\
$\mathrm{CaO}$ & 12.04 & 11.91 & 11.79 & 11.81 & 10.59 & 11.78 & 11.12 & 11.19 & 10.95 \\
$\mathrm{MgO}$ & 1.15 & 1.13 & 1.28 & 1.22 & 0.87 & 0.95 & 0.92 & 0.95 & 0.92 \\
$\mathrm{SO}{ }_{3}$ & 0.84 & 0.87 & 0.91 & 0.90 & 0.75 & 0.81 & 0.79 & 0.81 & 0.80 \\
$\mathrm{~K}_{2} \mathrm{O}$ & 5.28 & 5.66 & 6.20 & 5.58 & 4.39 & 4.54 & 4.79 & 4.72 & 4.52 \\
$\mathrm{Na}_{2} \mathrm{O}$ & 1.18 & 1.17 & 1.23 & 1.31 & 1.14 & 0.98 & 1.37 & 1.32 & 1.10 \\
$\mathrm{P}_{2} \mathrm{O}_{5}$ & 1.07 & 1.13 & 1.20 & 1.24 & 0.80 & 1.04 & 0.94 & 0.96 & 0.86 \\
$\mathrm{Mn}_{2} \mathrm{O}_{3}$ & 0.13 & 0.19 & 0.19 & 0.19 & 0.13 & 0.17 & 0.14 & 0.15 & 0.14 \\
$\mathrm{TiO}_{2}$ & 0.39 & 0.45 & 0.43 & 0.41 & 0.36 & 0.43 & 0.40 & 0.42 & 0.40 \\
$\mathrm{~L} . \mathrm{O}$. I. & 10.72 & 10.58 & 10.66 & 10.61 & 9.27 & 10.29 & 9.75 & 9.82 & 9.60 \\
$\mathrm{LSF}$ & 7.19 & 7.36 & 7.43 & 7.24 & 5.76 & 7.03 & 6.43 & 6.51 & 6.23 \\
$\mathrm{Silica}$ Ratio & 5.30 & 5.08 & 5.17 & 5.31 & 5.20 & 5.76 & 5.28 & 5.27 & 5.34 \\
$\mathrm{Alumina}$ Ratio & 2.41 & 3.06 & 2.71 & 2.54 & 1.87 & 2.73 & 2.70 & 2.56 & 2.14 \\
$\mathrm{CaCO}_{3}$ & 21.49 & 21.24 & 21.04 & 21.08 & 18.92 & 21.02 & 19.86 & 19.98 & 19.54 \\
$\mathrm{~L} . \mathrm{O}$. I. & 10.72 & 10.58 & 10.66 & 10.61 & 9.27 & 10.29 & 9.75 & 9.82 \\
$\mathrm{Sum}$ of Conc. & 100.00 & 100.00 & 100.00 & 100.00 & 100.00 & 100.00 & 100.00 & 100.00 & 9.60 \\
$\mathrm{C}_{3} \mathrm{~S}$. & -669.84 & -667.69 & -659.13 & -666.25 & -724.65 & -695.11 & -705.97 & -702.90 & -713.00 \\
$\mathrm{~S}+\mathrm{A}+\mathrm{F}$ & 67.19 & 66.92 & 66.12 & 66.74 & 71.69 & 69.02 & 69.78 & 69.66 & 70.70 \\
\hline
\end{tabular}




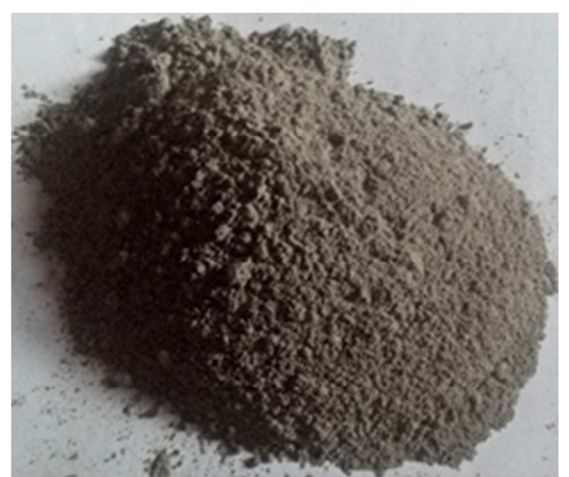

(a)

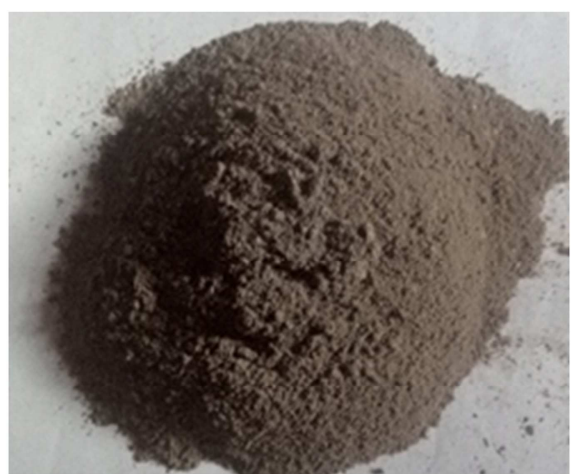

(b)

Figure 1. (a) Portland Limestone cement (b) Sugarcane Bagasse ash.

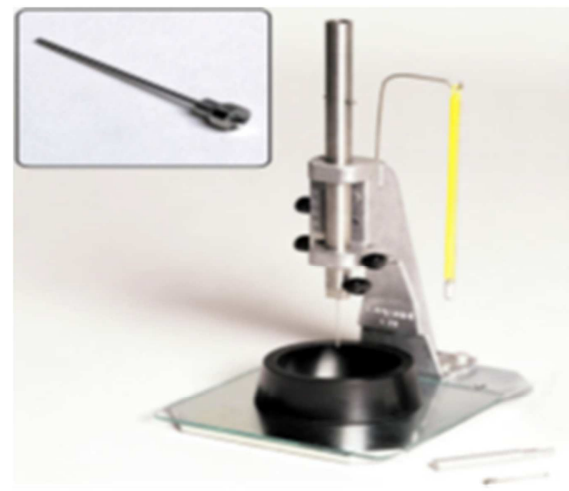

(a)

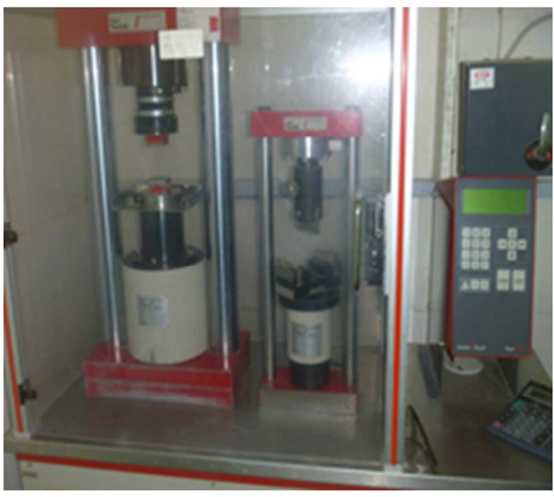

(b)

Figure 2. (a) Vicat apparatus and (b) Toni Technik compression machine.

\subsection{Effect of SCBA Content on the Water Demand/ Consistency of PLC Blends}

Table 4 tabulates the influence of SCBA content on cement properties such as water consistency (water demand), setting times, volume expansion and specific gravity of various cement blends respectively. The variation in SCBA content at different percentage levels on water consistency (water demand) for binary cement PLC-SCBA blends are illustrated in Figure 3.

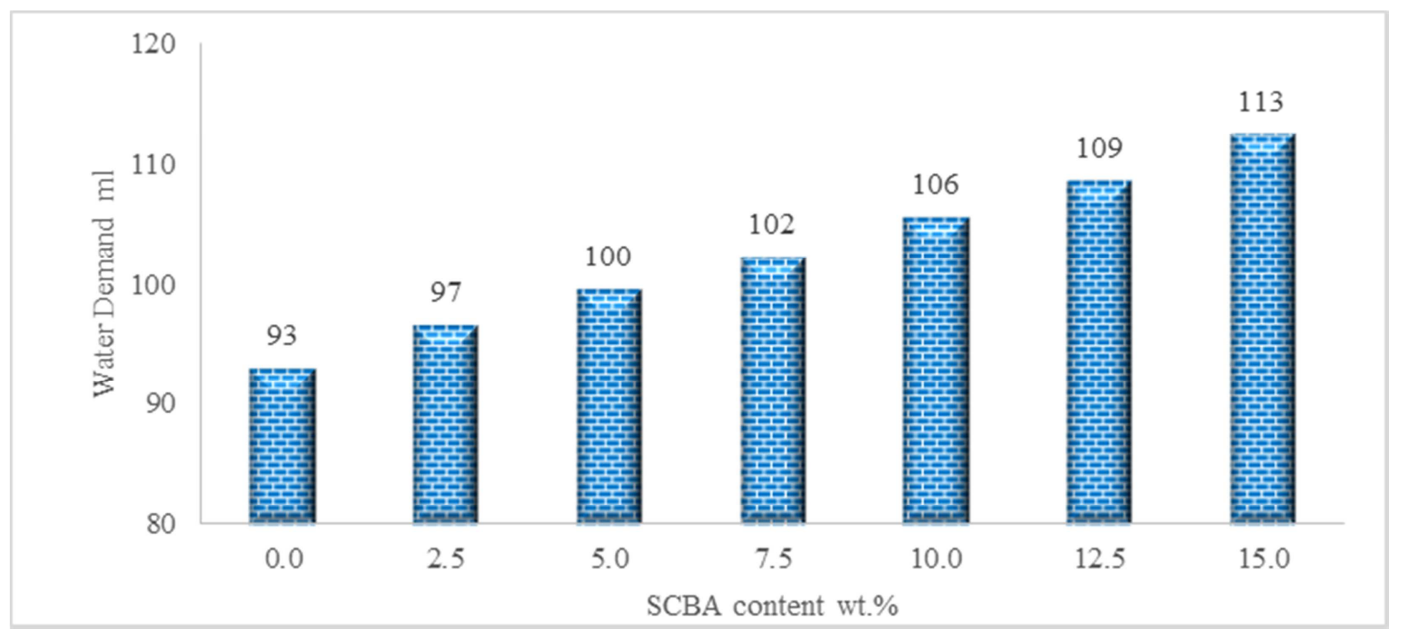

Figure 3. Effect of SCBA content on the water demand of binary cement blend.

Table 4. Effect of SCBA on the normal consistence, water demand setting times, specific gravity and soundness of cement blends.

\begin{tabular}{llllll}
\hline $\begin{array}{l}\text { SCBA content } \\
(\mathbf{w t .} \%)\end{array}$ & Water consistency $(\%)$ & $\begin{array}{l}\text { Water demand } \\
(\mathbf{m l})\end{array}$ & IST (mins) & FST (mins) & $\begin{array}{l}\text { Vol. expansion } \\
(\mathbf{m m})\end{array}$ \\
\hline 0.0 & 31.0 & 93.0 & 190 & 295 & 1.0 \\
2.5 & 32.2 & 96.6 & 92 & 139 & 1.0 \\
5.0 & 33.2 & 99.6 & 95 & 152 & 1.0 \\
\hline
\end{tabular}




\begin{tabular}{lllllll}
\hline $\begin{array}{l}\text { SCBA content } \\
(\mathbf{w t .} \%)\end{array}$ & Water consistency $(\%)$ & $\begin{array}{l}\text { Water demand } \\
(\mathbf{m l})\end{array}$ & IST (mins) & FST (mins) & $\begin{array}{l}\text { Vol. expansion } \\
(\mathbf{m m})\end{array}$ & Specific gravity \\
\hline 7.5 & 34.1 & 102.3 & 99 & 160 & 1.0 & 2.77 \\
10.0 & 35.2 & 105.6 & 110 & 177 & 1.5 & 2.69 \\
12.5 & 36.2 & 108.6 & 122 & 182 & 1.5 & 2.67 \\
15.0 & 37.5 & 112.5 & 138 & 199 & 2.0 & 2.65 \\
\hline
\end{tabular}

An increase in the water consistence of SCBA-PLC paste from $31.0-37.5 \%$ was experienced as cement was gradually replaced by SCBA content from 0 - 15 wt.\%. Similarly, the water demand experienced an increase from 93 to $112.5 \mathrm{~mm}$ (by $21 \%$ ) as the SCBA content was increased. The water demand for SCBA-cement blends were observed to be higher compared with PLC control. This increase could be attributed to higher burnt carbon content of SCBA which is evident by a high LOI value of $9.27 \%$ in comparison with ASTM C 618 standards. Similar trend was observed by Yashwanth and Nareshkumar [42], Sachin et al. [16] and Geerthana et al. [26] on the normal consistency as SCBA was increased and they attributed its increase to the SCBA fineness thus, requiring more water. This high unburnt carbon can increase the water requirement for normal consistence which agrees with research works of Kaya [40], Olubajo et al. [43] and Georgescu and Saca [44] respectively. Another reason for the higher water requirement could be due to the high silica content thus, imparting on the workability of the cement blend.

\subsection{Effect of SCBA Content on the Setting Times of PLC Blends}

The results of both setting times of the SCBA cement blends presented in Table 4 were within the limit as recommended by ASTM C 595 [35] while Figure 4 illustrated the effect of cement replacement on the setting times of SCBA cement blends. The setting times of SCBA cement blends at various cement replacements were found to be lower than PLC. This elongation of the setting times of SCBA cement blends compared to PLC could be attributed to the diminution of clinker content as a result of a decrease in calcium silicate and high-water requirement owing to presence of unburnt carbon which agrees with works by Olubajo and Osha [41], Kaya [40] and Georgescu and Saca [44] respectively. The SCBA cement blend up to 15 wt.\% replacement retarded the initial and final setting time by 46 and 60 minutes in comparison with PLC control. Another reason for the retarded setting times could be due to the increase in the potassium ion (4.39 wt.\%) present in SCBA resulting in formation of muscovite which is considered a retarder according to Olubajo et al. [5, 43] and Venkateswara et al. [45].

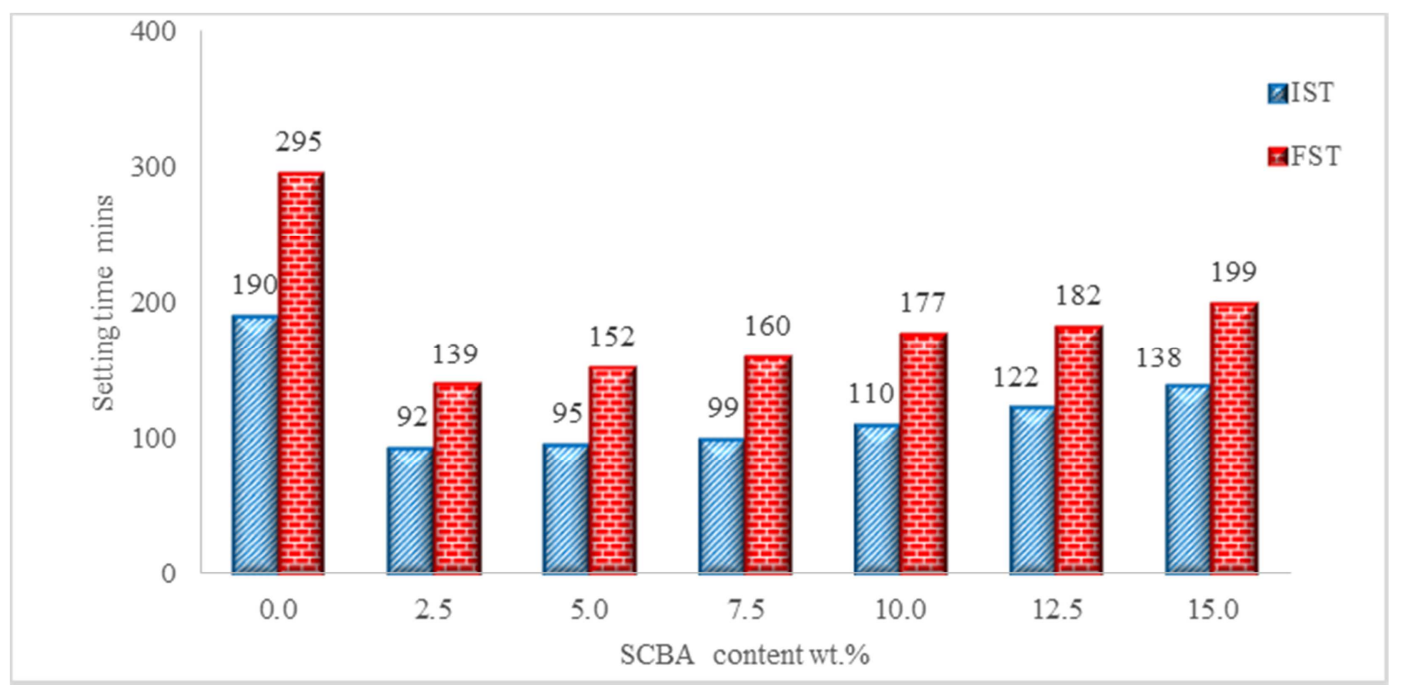

Figure 4. Effect of cement replacement on the setting time of SCBA cement blends.

\subsection{Effect of SCBA on the Specific Gravity}

The effect of SCBA content on the specific gravity of SCBA -PLC cements are also presented in Table 4. The specific gravities of SCBA-PLC cements were found to be lower compared to those of PLC. The specific gravity of SCBA cement blend diminished by $8.62 \%$ as SCBA content was increased from $0-15$ wt. \% as illustrated in Figure 5 which could be attributed to PLC's specific density being higher than SCBA.

\subsection{Effect of SCBA Content on the Soundness (Volume Expansion) of PLC Blends}

The effect of SCBA content on the volume expansion of various cement blends was tabulated in Table 4 were determined via Le Chatelier apparatus. It could be observed from Figure 6 that as the cement replacement with SCBA increased from 2.5 - $15 \mathrm{wt} . \%$, the volume expansion gradually increased from $1-2 \mathrm{~mm}$, owing to an increase in the available free lime. This gradual increase could be due to relatively 
moderate lime content (10.59 wt.\%) present in the SCBA.

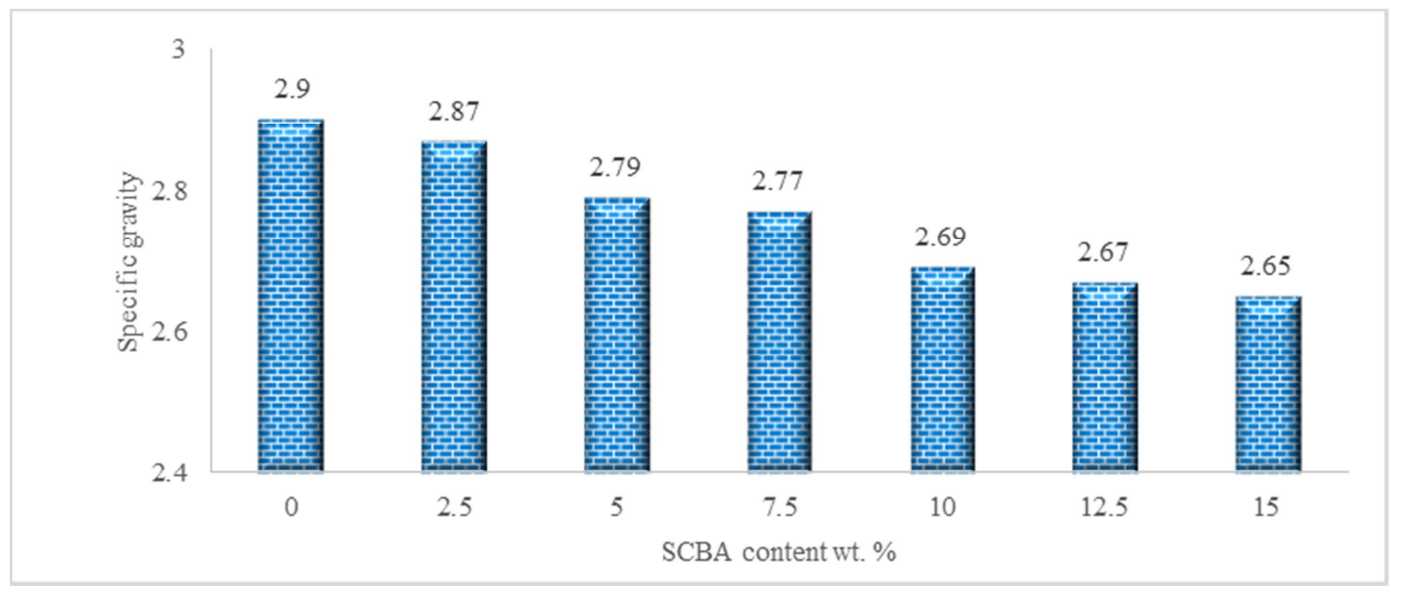

Figure 5. Effect of SCBA content on Specific gravity of cement blends.

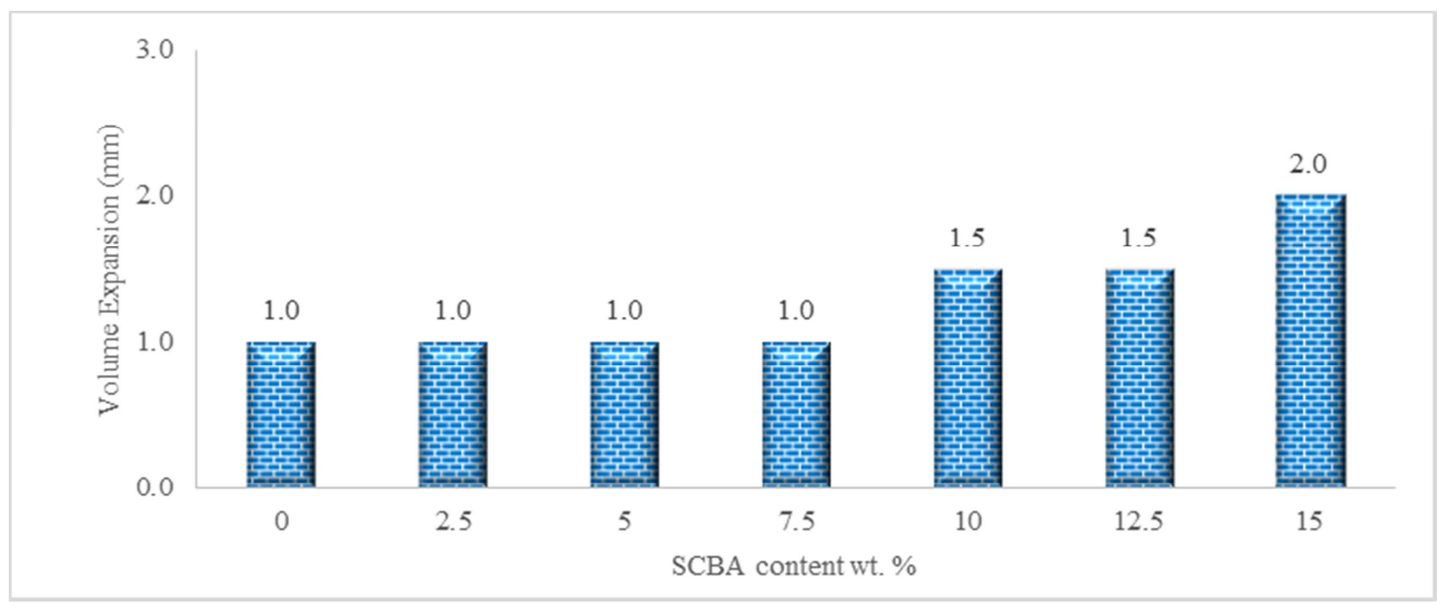

Figure 6. Effect of SCBA content on volume expansion of cement blends.

\subsection{Effect of SCBA Content on the Mortar Strength of PLC} Blends

The effect of SCBA content on the mortar compressive strength and the rate of water absorption of blended cement mortars are tabulated in Table 5. A moderate decrease in the mortar compressive strength of SCBA cement blends were observed especially at higher SCBA content between 7.5 -15 wt.\% (attaining between $82-93 \%$ of 28 days control strength). These reductions in their strengths could be linked to the high unburnt carbon in the ash coupled with dilution of Portland cement compounds.

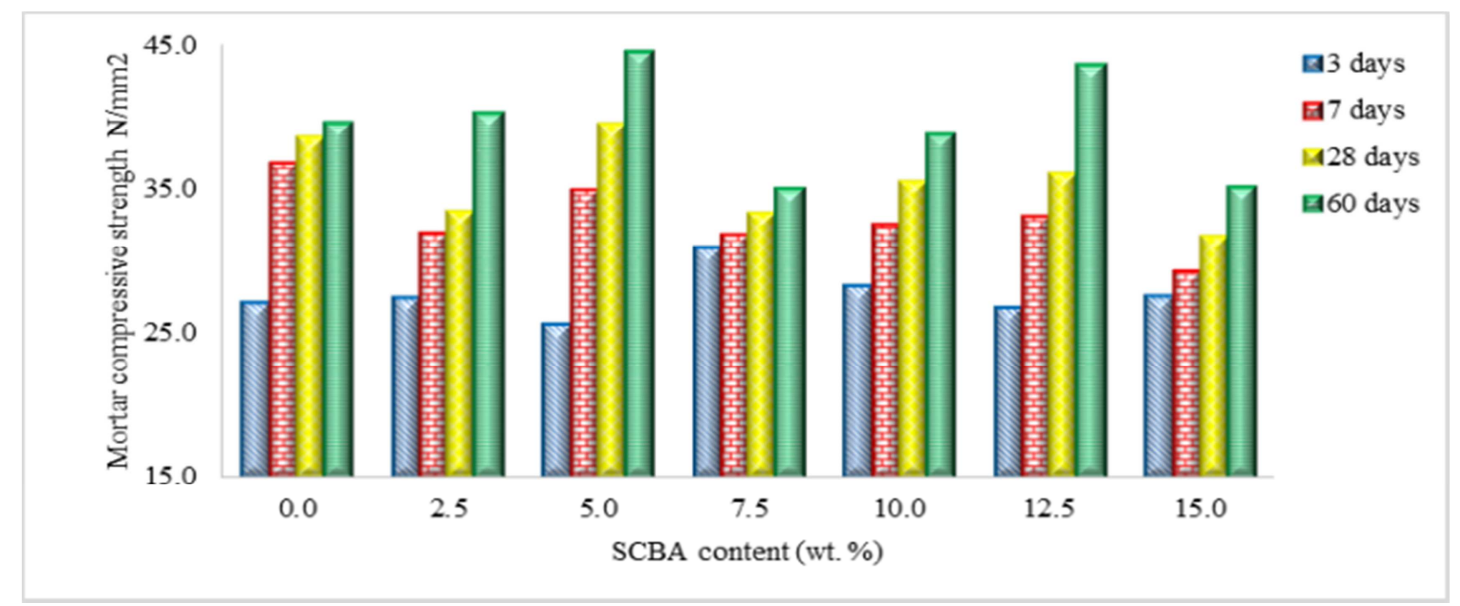

Figure 7. Effect of SCBA content on the mortar compressive strength of cement blends. 
Table 5. Effect of SCBA content on the mortar compressive strength and water absorption rate of SCBA cement blends at various cement replacement.

\begin{tabular}{|c|c|c|c|c|c|}
\hline S/No & SCBA content $w t . \%$ & 3 days $N / \mathrm{mm}^{2}$ (wt.\%) & 7 days $N / \mathrm{mm}^{2}$ (wt. $\%$ ) & 28 days $\mathrm{N} / \mathrm{mm}^{2}$ (wt. $\%$ ) & 60 days $\mathrm{N} / \mathrm{mm}^{2}$ (wt.\%) \\
\hline 1 & 0.0 & $27.2(1.73)$ & $36.7(1.98)$ & $38.6(3.77)$ & $39.6(3.84)$ \\
\hline 2 & 2.5 & $27.5(1.59)$ & $31.9(2.40)$ & $33.5(3.41)$ & $40.3(3.93)$ \\
\hline 3 & 5.0 & $25.7(1.63)$ & $34.9(2.30)$ & $39.5(3.69)$ & $44.6(3.75)$ \\
\hline 5 & 10.0 & $28.3(1.72)$ & $32.5(2.23)$ & $35.5(3.26)$ & $38.9(3.37)$ \\
\hline 6 & 12.5 & $26.8(1.52)$ & $33.1(2.01)$ & $36.1(3.53)$ & $43.6(4.39)$ \\
\hline 7 & 15.0 & $27.6(1.49)$ & $29.3(1.79)$ & $31.7(3.73)$ & $35.2(4.35)$ \\
\hline
\end{tabular}

Figures 7 and 8 illustrate the effect of cement replacement on the mortar compressive strength and water absorption rate of various cement blends respectively. It was observed that as the curing days progressed from 3 to 60 days, the control and SCBA-PLC blends experienced increments in their mortar compressive strengths by $45.87,46.72,73.61,13.44,37.54$, 62.61 and $27.39 \%$ for $0,2.5,5,7.5,10,12.5$ and 15 wt. $\%$ respectively. Most of the cement blends at 3 days produced compressive strengths better than control and could be attributed to the presence of available lime from the SCBA which tends to accelerate the hydration assembly. Thus, favoring formation of ettringite at the expense of monosulfate, leading to early hydration rates especially at 3 days despite the clinker diminution [9]. Similarly, most of the compressive strength of the cement blends were greater than $80 \%$ of the control's compressive strength at the various curing days. This enhanced strength experienced by the cement blends despite clinker diminution could be evident that pozzolanic reaction occurred $[6,41,44,46]$. Whereas, on the other hand, a series of increase and decrease in its mortar compressive strengths were experienced as the cement replacement was increased from $0-15$ wt. $\%$ at intervals of 2.5 wt. $\%$.

These reductions could also be due to the higher water required to attain consistence which results in diminished strengths in comparison with control. Table 6 presents the percentage mortar compressive strength of SCBA-PLC blend against PLC control strength at a given curing day. Cement replacement of $2.5,7.5,10$ and 15 wt.\% at 3 days produced percentage compressive strength of $101.08 \%, 113.80 \%$,
$104.03 \%$ and $101.62 \%$ of the control's 3 days compressive strength respectively. On the other hand, $86.77 \%, 86.31 \%$, $92.12 \%, 93.57 \%$ and $82.21 \%$ of the 28 days compressive strength of the control were attained for $2.5,7.5,10,12.5$ and 15 wt.\% cement replacement with SCBA respectively. Thus, the optimal SCBA cement replacement should not exceed 5 wt.\%. Cement replacement of $5 \mathrm{wt} . \%$ SCBA produced a lower 3 days mortar strength compared to those of PLC. There was an enhanced strength from 25.7 to $34.9 \mathrm{~N} / \mathrm{mm}^{2}$ (95\% of the control strength at 7 days) followed by a significant improvement to 39.5 and $44.6 \mathrm{~N} / \mathrm{mm}^{2}$ at 28 and 60 days respectively. The enhanced strength of $5 \mathrm{wt} . \%$ SCBA cement blend could be attributed to the pozzolanic activity resulting in formation of more $\mathrm{CSH}$ which adds to its strength despite clinker diminution [41]. Similarly, the compressive strength results for $12.5 \mathrm{wt} . \%$ SCBA experienced more than $90 \%$ for 3 , 7 and 28 days with an enhanced strength of $43.6 \mathrm{~N} / \mathrm{mm}^{2}$ at 60 days against $39.6 \mathrm{~N} / \mathrm{mm}^{2}$ of control.

The percentage compressive strength of $5 \mathrm{wt} \%$ SCBA- PLC blends produced exceptional compressive strength values of $102.54 \%$ and $112.47 \%$ as compared to the 28 and 60 days control strength respectively. Whereas at 12.5 wt.\% SCBA-PLC blend produced an enhanced strength of 43.6 $\mathrm{N} / \mathrm{mm}^{2}(110.05 \%)$ at 60 days in comparison with control. At 7.5 and 15 wt.\% cement replacement with SCBA produced the least compressive strength rate 80.71 and $80.94 \%$ at 60 days. Similar trend was also observed for the 28 days with SCBA -PLC blend strengths of 86.77 and $82.21 \%$ of PLC control.

Table 6. Compressive strengths of SCBA-PLC blends as a percentage of PLC.

\begin{tabular}{|c|c|c|c|c|c|}
\hline S/No & SCBA content wt. $\%$ & 3 days $\left(\mathrm{N} / \mathrm{mm}^{2}\right)$ & 7 days $\left(\mathrm{N} / \mathrm{mm}^{2}\right)$ & 28 days $\left(\mathrm{N} / \mathrm{mm}^{2}\right)$ & 60 days $\left(\mathrm{N} / \mathrm{mm}^{2}\right)$ \\
\hline 1 & 0.0 & $27.2(100.00 \%)$ & $36.7(100.00 \%)$ & $38.6(100.00 \%)$ & $39.6(100.00 \%)$ \\
\hline 2 & 2.5 & $27.5(101.08 \%)$ & $31.9(87.05 \%)$ & $33.5(86.77 \%)$ & $40.3(101.67 \%)$ \\
\hline 3 & 5.0 & $25.7(94.50 \%)$ & $34.9(95.01 \%)$ & $39.5(102.54 \%)$ & $44.6(112.47 \%)$ \\
\hline 4 & 7.5 & $30.9(113.80 \%)$ & $31.8(86.72 \%)$ & $33.3(86.31 \%)$ & $35.1(88.49 \%)$ \\
\hline 5 & 10.0 & $28.3(104.03 \%)$ & $32.5(88.56 \%)$ & $35.5(92.12 \%)$ & $38.9(98.08 \%)$ \\
\hline 6 & 12.5 & $26.8(98.72 \%)$ & $33.1(90.28 \%)$ & $36.1(93.57 \%)$ & $43.6(110.05 \%)$ \\
\hline 7 & 15.0 & $27.6(101.62 \%)$ & $29.3(79.86 \%)$ & $31.7(82.21 \%)$ & $35.2(88.74 \%)$ \\
\hline
\end{tabular}

\subsection{Effect of SCBA Content on the Water Absorption rate of $S C B A-P L C$ Mortars}

Figure 8 indicates the influence of SCBA content on the rate of water absorption of cement mortars. An increase in the rate of water absorption of the mortars were observed as the curing days progressed from 3 to 60 days. A significant increase in the rate of water absorption of the SCBA mortars was observed due to the high absorptive capacity of SCBA, thus as its content was increased, resulted in an increase in the rate of water absorptive capacity of the SCBA mortars especially at 28 and 60 days as compared with 3 and 7 days. 


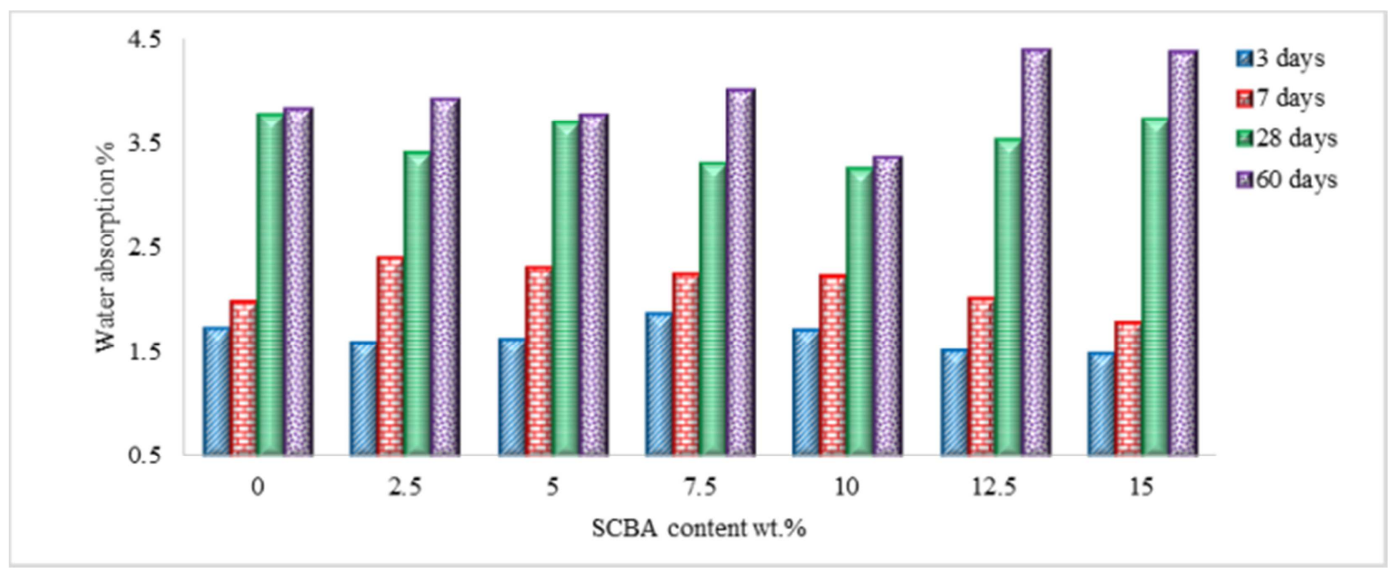

Figure 8. Effect of SCBA content on the rate of water absorption of cement blend.

On the other hand, a variation in the rate of water absorption of SCBA mortars was observed as SCBA content was gradually increased from $0-15 \mathrm{wt} . \%$ at given curing ages of $3,7,28$ and 60 days respectively.

\section{Conclusion}

The following conclusions on the investigation of SCBA as a potential cement replacement material are as follows:

The optimal condition for calcination of Sugarcane bagasse sample was obtained at $650^{\circ} \mathrm{C}$ for 90 minutes owing to the fact that it had the highest sum total for $\mathrm{SiO}_{2}, \mathrm{Al}_{2} \mathrm{O}_{3}$ and $\mathrm{Fe}_{2} \mathrm{O}_{3}$ as 71.79 wt.\% in comparison with other samples. The chemical analysis via X-ray fluorescence spectrometer revealed that SCBA contained mainly of lime, silica and potassium oxide with $\mathrm{SiO}_{2}+\mathrm{Al}_{2} \mathrm{O}_{3}+\mathrm{Fe}_{2} \mathrm{O}_{3}(71.79$ wt.\%) greater than $70 \%$, with $\mathrm{CaO}$ content $>10 \%$ at 10.29 wt.\% which met Class $\mathrm{C}$; hence the ash satisfies as a pozzolan according to ASTM C618.

The water demand (water consistency) increased by $21 \%$ as the SCBA content increased from $0-15 \mathrm{wt} . \%$ at intervals of 2.5 wt. $\%$ which was attributed to the unburnt carbon contributed by SCBA's high LOI. The initial and final setting time of the cement blends indicated a retardation by 46 and 60 minutes as the SCBA content was increased from $2.5-15 \mathrm{wt} . \%$ respectively. The elongated setting times was attributed to either the diminution of the clinker content and high-water requirement. The inclusion of SCBA in cement serves as a retarder in a binary cement due to the significant potassium oxide content while the high $\mathrm{SiO}_{2}$ content of SCBA which serves as strengthening agent. The specific gravity of SCBA cement blends diminished by $8.62 \%$ while the volume expansion of SCBA-PLC blends increased as the SCBA was increased from $0-15 \mathrm{wt} \%$. A significant reduction in their specific gravities by 2.79 and $2.89 \%$ was experienced between 2.5 to 5 wt. $\%$ and 7.5 to $10 \mathrm{wt} \%$ SCBA PLC blends. The diminished specific gravities of the SCBA-PLC are linked with the lower specific gravity of SCBA compared to PLC while the soundness (volume expansion) of the SCBA-PLC blends increased from $1-2 \mathrm{~mm}$ due to inclusion of SCBA with moderate lime content.
An increase in the mortar compressive strength was observed as the curing days progressed. The early 3 days strength of the SCBA-PLC blends were higher than control and could be attributed to the presence of lime which favor the formation of nucleation sites which enhance hydration rate of cements. The enhanced strength was observed at 2.5, 5 and 12.5 wt. \% cement replacement at 60 days which could be due to pozzolanic activity owing to the interaction between silica from the SCBA and available lime remaining after cement hydration of clinker despite clinker diminution. Results indicated a maximum mortar compressive strength of 39.5 and $44.6 \mathrm{~N} / \mathrm{mm}^{2}$ for 28 and 60 days respectively, while a maximum strength of $34.9 \mathrm{~N} / \mathrm{mm}^{2}$ at 7 days at $5 \mathrm{wt} . \%$ cement replacement. Whereas, the 3 days maximum compressive strength of the mortar was obtained at $7.5 \mathrm{wt} . \%$. It could also be revealed that replacement with SCBA up to $12.5 \mathrm{wt} \%$ produced an enhanced strength of $43.6 \mathrm{~N} / \mathrm{mm}^{2}$ at 60 days $(110.05 \%)$ and any further replacement led to diminution of its strength. The physico-mechanical properties of SCBA-PLC blends did not significantly deviate from control. An increase in the water absorption rate of the mortars by $33.94 \%$ was experienced as the curing days progressed while as the cement replacement with SCBA content was increased from $0-15$ wt. \% led to a variation in the rate of water absorption of SCBA - PLC mortars.

\section{Acknowledgements}

The authors wish to thank Ashaka Cement Plc., Nigeria and the Department of Chemical Engineering and Civil Engineering of Abubakar Tafawa Balewa University, Bauchi Nigeria for providing infrastructure, facilities and their support to this research work.

\section{References}

[1] Reddy, B. D., Jyothy, S. A., and Babu, P. R. (2013). Experimental investigation on concrete by partially replacement of ware aggregate with junk rubber, The International Journal of Engineering and Science (IJES), 2 (12), 61-65. 
[2] Elinwa, A. U., and Ejeh, S. P. (2014). Effects of incorporation of saw dust waste incineration fly ash in cement pastes and mortar, Journal of Asian Architecture and Building. Engineering, 3 (1), 1-7.

[3] Prakash, R. (2017). Mechanical properties of concrete with partial replacement of bagasse ash. International Journal of Advance Engineering and Research Development, 4 (7), 14-20.

[4] Mujedu, K. A., Adebara, S. A., and Lamidi, I. O. (2014). The use of corn cob ash and saw dust ash as cement replacement in concrete works. The International Journal of Engineering and Sciences (IJES), 3 (4), 22-28, April, 2014. Available at http://www.theijes.com.

[5] Olubajo, O. O., Abdullahi, B., and Osha, O. A. (2019). The potential of orange peel ash as a cement replacement material. Path of Science, 6 (2), 1629-1635. Available on website link: http://www.pos.org.

[6] De Weerdt, K., Kjellsen, K. O., Sellevold, E., and Justnes, H. (2011). Synergy between fly ash and limestone powder in ternary cements. Cement and Concrete Composites, 33 (1), 30 -38. doi: 10.1016/j.cemconcomp. 2010.09.006.

[7] Gowsika, D., Sarankokila, S., and Sargunan, K. (2014). Experimental investigation of egg shell powder as partial replacement with cement in concrete. 14 (2) Aug 2014.

[8] Raheem, A. A., Olasunkanmi, B. S., and Folorunso, C. S. (2012). Saw dust ash as partial replacement for cement in concrete. Organization, Technology and Management in Construction and International Journal, 4 (2), 474-480.

[9] Olubajo, O. O., Osha, A. O., El- Nafaty, U. A., and Adamu. H. A. (2017). A study on Coal bottom ash and limestone effects on the hydration and physico-mechanical properties of ternary cement blends. Ph. D. Thesis. Abubakar Tafawa Balewa University, Bauchi, Nigeria.

[10] Neville, H. (2016). A study on the structural design of concrete produced by partial replacement of pozzolanic materials. International Journal of Scientific and Engineering Research, 9 (3), 114-119.

[11] Someswara, R. B., Vidya, S. L. N., and Naveen, G. (2015). Durability studies on concrete and comparison with partial replacement of cement with rice husk ash and sugarcane bagasse ash in concrete. Int. Journal of Engineering Research and Applications (Part - 4), 5 (11), 52-58.

[12] Vikas, S., Imam, A. A., Mehta, P. K. and Singh, R. K. (2020). Supplementary cementitious materials in construction and attempt to reduce $\mathrm{CO}_{2}$ emission. Journal of Environment Nanotechnology, 9, (3) 41-44.

[13] Cabrera, J. G., and Lynsdale, C. J. (2013). A new gas permeameter for measuring the permeability of mortar and concrete. Magazine of Concrete Research, 40 (144), 177-182.

[14] Thirumalai, R. K., and Murthi, P. (2015). Bagasse ash and rice husk ash as cement replacement in self-compacting concrete Građevinar 67 (1), 23-30.

[15] Ganesh, B. M., and Shiny, P. G. (2015). Investigational study on bagasse ash in concrete by partially substitute with cement. International Journal of Computer Engineering in Research Trends, 2 (12), 1044-1048.

[16] Sachin, K., Manisha, B., and Ashwini, P. (2017). Effect of cement replacement by sugarcane bagasse ash and glass powder on mortar and concrete. International Journal for Research in Applied Science \& Engineering Technology (IJRASET), 5 (9), 240-244.

[17] Modani, P. O., and Vyawahare, M. R. (2013) Utilization of bagasse ash as a partial replacement of fine aggregate in concrete Chemical, Civil and Mechanical Engineering Tracks of 3rd Nirma University International Conference on Engineering (NUiCONE 2012) Procedia Engineering, 51, 2529.

[18] Hussein, A., Shafiq, N., and Nuruddin, M. F. (2017). Sudanese sugar cane bagasse ash: a valuable by-product for concrete. International Journal of Structural and Civil Engineering Research, 6 (4), 238-244.

[19] Chusilp, N., Jaturapitakkul, C., and Kiattikomol, K. (2009). Effects of LOI of ground bagasse ash on the compressive strength and sulfate resistance of mortars. Construction and Building Materials, 23 (12), 3523-3531.

[20] Ganesan, K., Rajagopal, K., and Thangavel, K. (2007). Evaluation of bagasse ash as supplementary cementitious material. Cement and Concrete Composites, 29 (6), 515-524.

[21] Srinivasan, R. (2010). Experimental study on bagasse ash in concrete, 5 (2), 60-66.

[22] Suvimol, S., and Daungruedee, C. (2008). Bagasse ash: effect of pozzolanic activity and application in cement use aspect 165-173.

[23] Bhargavi, P., and Murali, K. (2018). An experimental study on partial replacement of cement with bagasse ash in concrete mix. International Journal of Civil Engineering and Technology (IJCIET) 9 (5), 175-184.

[24] Mashair, K. I., and Kamal, E. E. Y. (2016). Utilization of local materials (pozzolana, sugarcane bagasse ash or local sand) in reducing clinker cost. International Journal of Innovative Science, Engineering \& Technology IJISET, 3 (4), 453-461.

[25] Bangar, S. S., Phalke, S. N., Gawade, A. Y., Tambe, R. S., and Rahane, A. B (2017). A review paper on replacement of cement with bagasse ash. International Journal of Engineering Sciences and Management, 7 (1), 127-131.

[26] Geerthana, R., Gnanasoundari, J., Madheswari, T., Vetriselvi, K., and Selvarani, S. (2016). Evaluation of sugarcane bagasse ash as a partial replacement of cement in concrete. International Journal of Advanced Research Trends in Engineering and Technology (IJARTET), 3 (2), 666-672.

[27] Sivakumar, G., Hariharan, V., and Barathan, S. (2013) Preparation of bio-cement using sugarcane bagasse ash and its hydration behavior. International Journal of Science, Engineering and Technology Research (IJSETR), 2 (10), 1887-1889.

[28] Reddy, M. V. S., Ashalatha, K., Madhuri, M., and Sumalatha, P. (2015). Utilization of sugarcane bagasse ash (SCBA) in concrete by partial replacement of cement. IOSR Journal of Mechanical and Civil Engineering (IOSR-JMCE). 12 (6), 12-16.

[29] Mangi, S. A., Jamaluddin, N., Wan Ibrahim, M. H., Abdullah, A. H., Abdul Awal, A. S. M., Sohu, S., and Ali N. (2017). Utilization of sugarcane bagasse ash in concrete as partial replacement of cement. IOP Conf. Series: Materials Science and Engineering, 271, 1-9. 
[30] Romildo, A. B., Fernando, A. N. S., Eliana, C. B. M., Cecilia, S L., and Analice, L. (2016). Effect of sugarcane bagasse ash as partial replacement of cement on mortar mechanical properties. Electronic Journal of Geotechnical Engineering (EJGE), 21 Bund 12, 4577-4586.

[31] Anvesh, S., and Chamanthi, P. (2017). Study on behavior of partial replacement of cement with sugarcane bagasse ash for high strength concrete mix. International Journal of Advanced Technology and Innovative Research (IJSATIR), 9 (1), 171-176.

[32] Yasir, A. A. M., Shihab, A. K., Salah, E. F. H., and Hassan, A. E (2017). Effects of sugarcane's bagasse ash additive on Portland cement properties. International Journal of Sustainable Development Research. 3 (6), 85-89.

[33] Rauf, N., Damayanti, M. C., and Pratama, S. W. I. (2017). The influence of sugarcane bagasse ash as fly ash on cement quality. AIP Conference Proceedings, 1801, 040009 1-3.

[34] ASTM C 187 (2010). Standard test method for normal consistency of hydraulic cement. Annual Book of ASTM Standards.

[35] ASTM C 595 (2010). Standard specification for blended hydraulic cements. Annual Book of ASTM Standards.

[36] EN 196-3 (2010). Methods of testing cement- part 3: determination of setting times and soundness. European Standards.

[37] ASTM C 618 (2008). Standard specification for coal fly ash and raw or calcined natural pozzolan for use in concrete. Annual Book of ASTM Standards.

[38] Külaots, I., Hurt, R. H., and Suuberg, E. M. (2004). Size distribution of unburned carbon in coal fly ash and its implications. Fuel, 83, 223-230.

[39] Freeman, E., Gao, Y. M., Hurt, R., and Suuberg E. (1996). Interactions of carbon containing fly ash with commercial air-entraining admixtures for concrete. Fuel, 76, 761-765.
[40] Kaya, A. (2010, September). A study on blended bottom ash cements (Master's thesis). Retrieved from http://etd.lib.metu.edu.tr/upload/12612504/index.pdf.

[41] Olubajo, O. O., and Osha, O. A. (2013). Influence of bottom ash and limestone powder on the properties of ternary cement and mortar. International Journal of Engineering Research and Technology 2 (7), 1201-1212 Available on website link: http://www.ijert.org.

[42] Yashwanth, M. K., and Nareshkumar, B. G. (2014). An experimental study on bagasse ash as replacement for cement in lightweight concrete. International Journal of Latest Trends in Engineering and Technology (IJLTET), 3 (3), 253-260.

[43] Olubajo, O. O., Osha, O. A., and Jibril, A. (2020). Setting times of Portland cement blended with locust bean pod and eggshell ashes. American Journal of Chemical Engineering, 8 (5), 103-111. doi: http://www.j.ajche.org10.11648/j.ajche.20200805.11.

[44] Georgescu, M., and Saca, N. (2009). Properties of blended cements with limestone filler and fly ash content. Scientific Bulletin, Series B, 71 (3), 13-14, 16.

[45] Venkateswara, R., Kontham, G., Venkata, R., and Chundupalli, S. (2011). Effect of potassium chloride $(\mathrm{KCl})$ on ordinary Portland cement (OPC) concrete. Research Journal of Chemical Sciences, 1 (2), 103-107.

[46] Lothenbach, B., Le Saout, G., Gallucci, E., and Scrivener, K. (2008). Influence of limestone on the hydration of Portland cements. Cement and Concrete Research, 38 (6), 848-860.

[47] ASTM C 109 (2008). Standard test method for compressive strength of hydraulic cement mortars. Annual Book of ASTM Standards.

[48] ASTM C 188 (2009). Standard Test Method for Density of Hydraulic Cement. Annual Book of ASTM Standards. 